\title{
Role of transcription factors in inflammatory lung diseases
}

Irfan Rahman, William MacNee

Acute and chronic alveolar and/or bronchial inflammation is thought to be central to the pathogenesis of many lung disorders such as asthma, chronic obstructive pulmonary disease (COPD), adult respiratory distress syndrome (ARDS), and idiopathic pulmonary fibrosis (IPF). The site and specific characteristics of the inflammatory responses may be different in each of these diseases, but all are characterised by the recruitment to the lungs and activation of immune and inflammatory cells. These activated cells produce cytokines, oxidants and many other mediators which are involved in inflammation. ${ }^{12}$ Recent data indicate that, in addition, airway epithelial cells are able to act as immune effector cells by secreting proinflammatory mediators, oxidants, and cytokines. $^{3}$ Once triggered, an inappropriate chronic inflammatory response persists in these conditions and is presumed to result in lung injury. The intracellular molecular mechanisms in response to environmental signals, leading to increased gene expression and biosynthesis of proinflammatory mediators by airspace inflammatory and epithelial cells, are of considerable current interest. It is now recognised that there are gene specific factors which regulate the transcription of particular genes by affinity binding to specific recognition motifs, which are usually located in the upstream (5') promoter region of the gene. These factors, which are usually located in the cytosol, can translocate to the cell nucleus and, by binding to specific consensus sites, can upregulate the rate of transcription of the gene and therefore increase the formation of messenger RNA (mRNA) and the protein of an inflammatory mediator. Some transcription factors are cell specific, but others are ubiquitous. Their activity can be modulated by environmental signals and they may play a key role in immune and inflammatory responses. The transcription factors about which there is most information in immune and inflammatory responses are nuclear factor-kappa $(\kappa) B(N F-$ $\kappa \mathrm{B})$ and activator protein $1(\mathrm{AP}-1){ }^{4}$ Other transcription factors include the nuclear factor for the IL-1 responsive element in the IL-6 gene (NF-IL6), nuclear factor of activated T cells (NFAT), glucocorticoid receptors (GR), cyclic AMP response element binding proteins (CREB), guanine-adenine and thymineadenine repeats (GATA), E26 transformation specific (ets), and the signal transducers and activators of transcription (STAT) families of transcription factors. The binding sites for these transcription factors are located in the promoter regions of a large variety of genes which are considered to be involved in lung inflammation..$^{5-7}$ In addition, there are several nuclear receptor co-activators which facilitate DNA binding of transcription factors, ${ }^{8}$ notably the CREB-binding protein (CBP), adenovirus E1A-associated protein $\mathrm{p} 300 / \mathrm{CBP}$-associated factor $(p / C A F)$, and the steroid receptor co-activator-1 (SRC-1), which interact with basal transcription factors and transcription machinery and are of particular importance in the transactivation and regulation of gene transcription involved in the immune and inflammatory responses. Understanding the function and regulation of basal transcription factors is fundamental to the study of lung inflammation and may provide novel therapeutic strategies for a number of inflammatory lung diseases. In this review we will focus on recent progress in our understanding of the role of the NF- $\mathrm{NB}$, AP-1, NF-IL6, and NFAT transcription factors in the pathogenesis of inflammatory lung diseases and discuss synergistic interactions between GR proteins, other families of transcription factors, and nuclear receptor coactivators which lead to specific gene regulation. We will also review the current concepts of pharmacological intervention to modulate the activation of these transcription factors.

\section{NF-кB}

REGULATION OF NF- $\kappa \mathrm{B}$

$\mathrm{NF}-\kappa \mathrm{B}$ was first identified as a nuclear factor that binds the decameric DNA sequence 5'-GGGACTTTCC-3' within the intronic immunoglobulin kappa light chain enhancer in mature B cells. ${ }^{9}$ Binding of NF- $\kappa \mathrm{B}$ to this DNA sequence is responsible for the inducible activity of the enhancer element present in the immunoglobulin gene. $\mathrm{NF}-\kappa \mathrm{B}$ is a member of the Rel family of proteins, a novel family of ubiquitous transcription factors sharing a common structural motif for DNA binding and dimerisation. ${ }^{10}$ The Rel family of transcription factors can be defined as a group of proteins that share sequence homology over a 300 amino acid region termed the $\mathrm{NF}-\kappa \mathrm{B} / \mathrm{Rel}$ domain. These proteins can exist either as homodimers or heterodimers, each with a specific affinity for different decamer binding sites fitting the $\kappa \mathrm{B}$ motif. ${ }^{10}$ Several different NF- $\kappa \mathrm{B}$ proteins have been characterised..$^{10}$ The classical activated form of NF- $\kappa \mathrm{B}$ is a heterodimer which usually consists of two proteins, a $65 \mathrm{kD}$ polypeptide (p65) subunit (also referred to as Rel A) and a $50 \mathrm{kD}$ polypeptide (p50) subunit. Other subunits, such as p105, a p50 precursor (NF- $\mathrm{kB} 1)$, p100, a precursor of p52 (NF$\kappa B 2), c-R e l$ and Rel B are present in different forms of NF- $\mathrm{BB}$. These subunits form various homodimers and heterodimers which are likely to have different affinities for DNA and different transactivation potentials of the complexes 


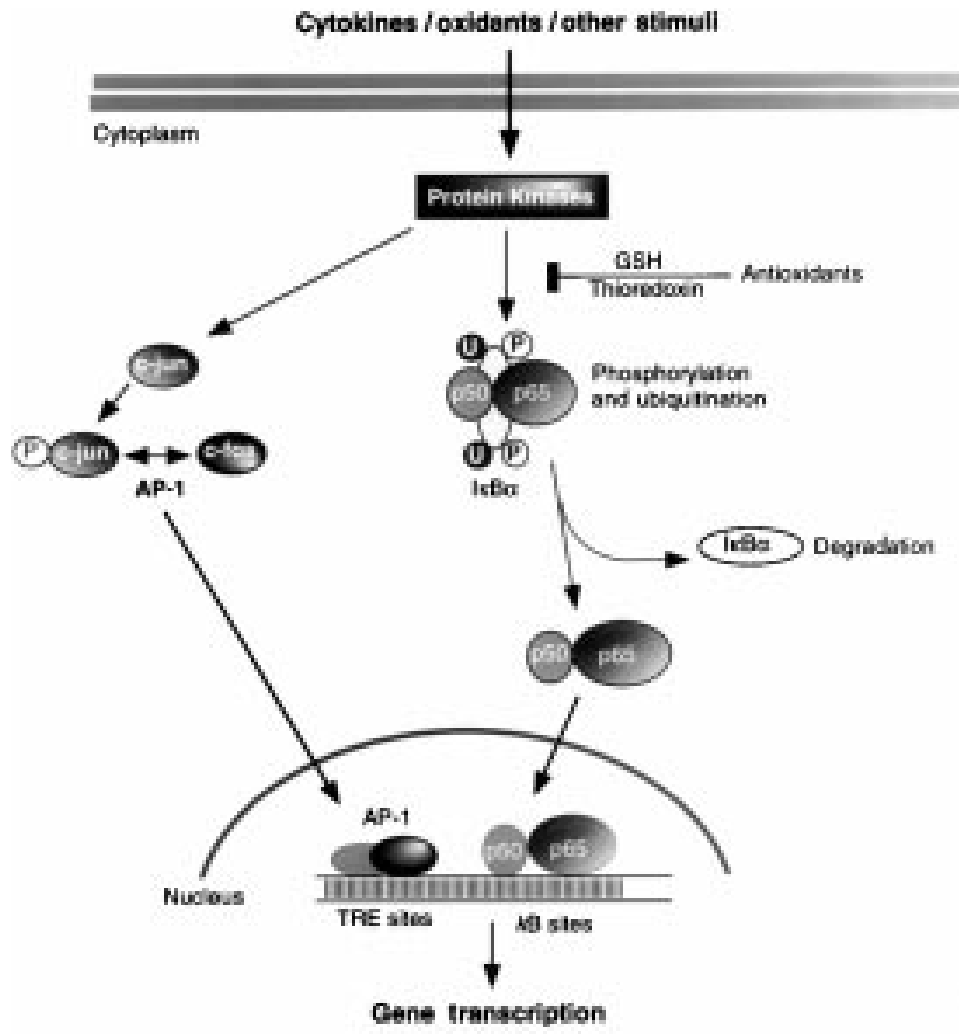

Figure 1 Model for the mechanism of $N F-\kappa B$ and $A P-1$ activation. Activation of $N F-\kappa B$ involves the phosphorylation, ubiquitination, and subsequent proteolytic degradation of the inhibitory protein I $\kappa$. Free $N F-\kappa B$ then translocates into the nucleus and binds with its $\kappa B$ consensus sites. Antioxidants such as intracellular glutathione and thioredoxin can inhibit $N F-\kappa B$ activation. Similarly, $A P-1$ either c-jun/c-jun (homodimer) or $c-f o s / c-j u n$ (heterodimer) migrates into the nucleus and binds with its TRE consensus regions. Activation of $N F-\kappa B / A P-1$ leads to gene expression of inflammatory proteins.

required to activate different sets of specific genes. In unstimulated cells $\mathrm{NF}-\kappa \mathrm{B}$ is found in the cytoplasm as an inactive non-DNA binding form, associated with an inhibitor protein called inhibitory $\kappa \mathrm{B}(\mathrm{I} \kappa \mathrm{B})$ which masks the nuclear translocation signal and so prevents $\mathrm{NF}-\kappa \mathrm{B}$ from entering the nucleus (fig 1). ${ }^{10}$ Upon cell stimulation-for example, by cytokines-specific kinases phosphorylate the

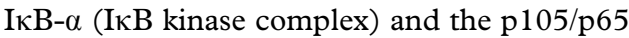
complex leading to their ubiquitination (transfer of the ubiquitin molecule). ${ }^{11}$ Ubiquitination of p105 results in an increase in the rate at which p105 is processed to p50, whereas ubiquitination of I $\mathrm{KB}-\alpha$ serves as a signal to the proteasome complex (proteolytic enzymes) to degrade rapidly and completely the I $\mathrm{B}$ unit in the cytoplasm. ${ }^{12}$ This critical release of NF- $\kappa B$ (p65/p50) from IאB results in the translocation of active p65/p50 into the nucleus where it binds to specific motifs in the promoter regions of target genes. The p50 subunit within the p50/p65 heterodimer greatly facilitates DNA binding, whereas the p65 subunit is required for adequate transactivation. ${ }^{10}$ A p50/p50 homodimer also binds to $\mathrm{\kappa B}$ sites but inhibits, rather than triggers, transcription. ${ }^{10}$ The importance of NF- $\mathrm{KB}$ subunits is highlighted by the fact that transgenic animals, which do not possess the genes coding for the p 50 or Rel B components of $\mathrm{NF}-\kappa \mathrm{B}$, have defects in both immune and inflammatory responses. ${ }^{13}$
Table 1 Activators of NF- $\kappa \mathrm{B}$

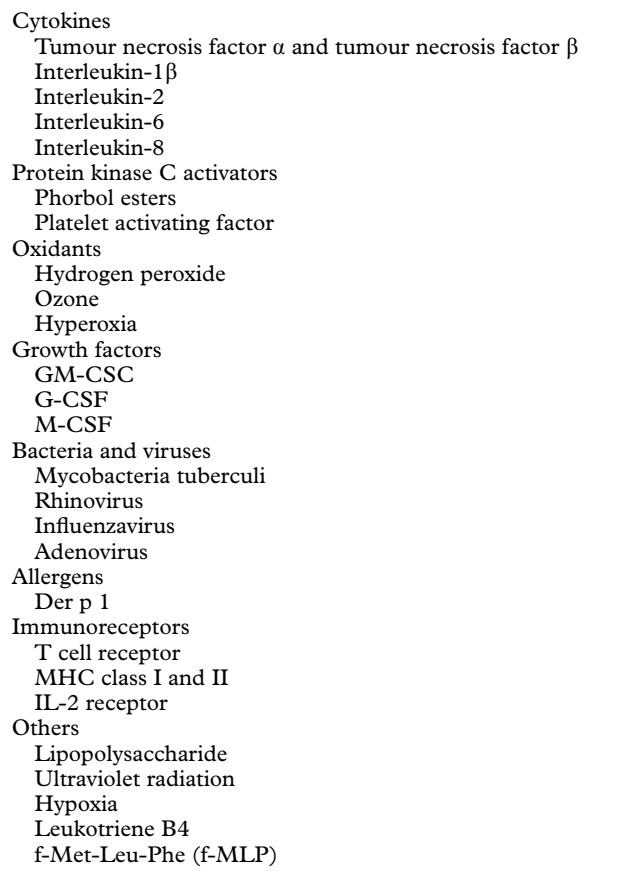

ACTIVATORS OF NF-אB

$\mathrm{NF}-\kappa \mathrm{B}$ activation represents the terminal step in a signal transduction pathway leading from the cell surface to the nucleus. A wide variety of extracellular stimuli trigger the activation of $\mathrm{NF}-\kappa \mathrm{B}$ (table 1) including pro-inflammatory cytokines, ${ }^{5}$ activators of PKC, ${ }^{10}$ allergens such as Der $p 1,{ }^{14}$ and bacterial and viral products. ${ }^{15-17}$ It may be through $\mathrm{NF}-\kappa \mathrm{B}$ activation that rhinovirus and influenza virus can trigger acute exacerbations of asthma. Experimental infection with rhinovirus activates $\mathrm{NF}-\kappa \mathrm{B}$ and stimulates the secretion of interleukin 6 (IL-6) in nasal epithelial cells. ${ }^{15}$

A conserved cysteine residue has been shown to be critical for both optimal DNA binding and redox regulation of $N F-\kappa B$ protein. ${ }^{18}$ Reactive oxygen intermediates (ROIs) have been recognised as important inducers of gene expression via $\mathrm{NF}-\kappa \mathrm{B}$ and AP-1. ${ }^{19}$ Many of the agents that activate NF- $\kappa \mathrm{B}$, such as TNF- $\alpha$, IL- $1 \beta$, lipopolysaccharide (LPS), and ultraviolet (UV) irradiation, also cause an increase in the cellular production of ROIs by mitochondria. ${ }^{20}$ ROIs have been directly implicated as second messengers in the activation of $\mathrm{NF}-\kappa \mathrm{B}$, based upon the ability of oxidants to activate NF- $\mathrm{NB}$ by oxidation of its cysteine-SH group or by ubiquitination and proteolysis. ${ }^{21}$ In addition, hyperoxia, ${ }^{22}$ ozone, ${ }^{23}$ and hydrogen peroxide $\left(\mathrm{H}_{2} \mathrm{O}_{2}\right),{ }^{24}$ iron catalysed lipid peroxidation, ${ }^{25}$ or depletion of reduced glutathione (GSH), and subsequent increases in cytosolic oxidized glutathione (GSSG) in response to oxidative stress rapidly ubiquitinate $\mathrm{NF}-\kappa \mathrm{B}$, which is a critical step for its activation. ${ }^{26}$

INHIBITORY $\kappa \mathrm{B}$ (ІкB)

I $\kappa$ B has several isoforms (I $\mathrm{B}-\alpha, \mathrm{I} \kappa \mathrm{B}-\beta, \mathrm{I} \kappa \mathrm{B}-\gamma$, I $\kappa \mathrm{B}-\delta, \mathrm{I} \kappa \mathrm{B}-\varepsilon)$, the most predominant being the $\alpha$ and $\beta$ subunits. ${ }^{10}$ These inhibitors have 5-7 
Table 2 Inhibitors of $N F-\kappa B$

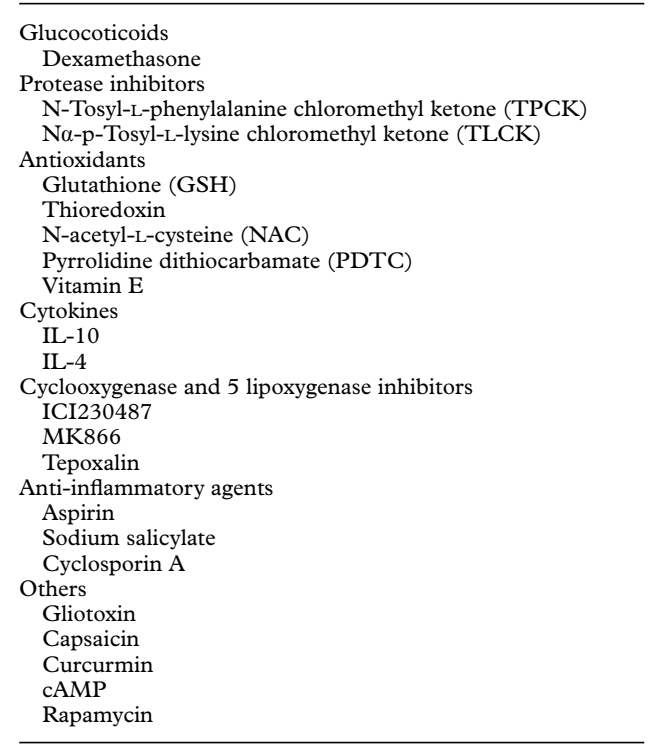

conserved domains known as ankyrin repeats, each consisting of around 30 amino acids, forming a unit which is able to interact with $\mathrm{NF}-\kappa \mathrm{B}$ subunits, thus masking the nuclear localisation signals and preventing activation of $\mathrm{NF}-\kappa \mathrm{B}$ and its translocation to the nucleus. ${ }^{10}$ The I $\kappa \mathrm{B}-\alpha$ and $\mathrm{I} \kappa \mathrm{B}-\varepsilon$ genes have an $\kappa \mathrm{B}$ recognition sequence in their promoter regions. ${ }^{1027}$ Thus, agents such as phorbol esters, which activate $\mathrm{NF}-\kappa \mathrm{B}$, will also induce the synthesis and activation of $I \kappa B-\alpha$ and IkB- $\varepsilon$ which enters the nucleus to bind to activated $N F-\kappa B$ and causes the return of $\mathrm{NF}-\kappa \mathrm{B}$ to the cytoplasm, thereby terminating gene activation. ${ }^{28}$ The importance of the inhibitory effect of I $\mathrm{B}$ is shown by the fact that disruption of I $\mathrm{K} B-\alpha$ in mice results in prolonged activation of NF- $\mathrm{NB}$ in response to inflammatory stimuli. In addition, animals treated in this way die of widespread inflammation. ${ }^{29}$

The IKB family contains other members, including $\mathrm{Bcl}-3$, I $\kappa \mathrm{B}-\gamma$, and $\mathrm{I} \kappa \mathrm{B}-\delta .^{30}$ The relative importance of these different inhibitors in regulating $\mathrm{NF}-\kappa \mathrm{B}$ activation is not clear, but the presence of multiple inhibitors is likely to be important in balancing the NF- $\mathrm{NB}$ activation and specific gene regulation.

INHIBITORS OF NF-KB

Several inhibitors of $\mathrm{NF}-\kappa \mathrm{B}$ activation have been shown to function by either preventing I $\mathrm{KB}$ degradation or by inducing IкB- $\alpha$ synthesis (table 2). The immunosuppressive and antiinflammatory actions of glucocorticoids have been shown to be mediated by the induction of I $\mathrm{B}-\alpha$ synthesis. ${ }^{31} \mathrm{~A}$ variety of other compounds can also inhibit NF- $\mathrm{KB}$ activation including tepoxalin, a dual inhibitor of cyclo-oxygenase and 5-lipoxygenase, ${ }^{32}$ the anti-inflammatory cytokine interleukin 10 (IL-10), ${ }^{33}$ and gliotoxin derived from Aspergillus fumigatus, ${ }^{34}$ However, the mechanism and specificity of inhibition of $\mathrm{NF}-\kappa \mathrm{B}$ by these agents remains unknown.

Antioxidants, such as the physiological intracellular redox regulators glutathione and thioredoxin, thioredoxin peroxidase, and the radical scavengers pyrrolidine dithiocarbamate (PDTC) and N-acetyl-L-cysteine (NAC), inhibit $N F-\kappa B$ activation by preventing the inducible decay of I $\kappa \mathrm{B}-\alpha$ in response to various stimuli. $^{35} 36$

\section{IKB KINASE(S)}

During the process of activation of NF- $\mathrm{NB}$ several signal transduction pathways are involved (fig 2). Recent studies have revealed the complexity of this process by demonstrating direct or indirect involvement of a number of known kinases in the phosphorylation event(s), particularly $\mathrm{NF}-\kappa \mathrm{B}$ inducing kinase (NIK) which has serine/threonine kinase activity homologous to the mitogen activated protein3-kinase (MAP3K) related kinase. ${ }^{37}$ However, a number of other kinases are possibly also involved in the activation of $\mathrm{NF}-\kappa \mathrm{B}$ DNA binding activity and $\kappa \mathrm{B}$ site dependent transcription. All of the stimuli which activate $\mathrm{NF}-\kappa \mathrm{B}$ act by means of kinases that phosphorylate and thus degrade I $\mathrm{B}$ by a proteasome mediated mechanism. ${ }^{11}$ Recently, a serine/ threonine kinase, CHUK, downstream of NIK, which is an NIK activated IKB- $\alpha$ kinase, has been characterised. ${ }^{38}$ Similarly, a cytokine responsive IKB kinase (IKK), almost identical to CHUK, has been described which specifically phosphorylates the critical serines 32 and 36 present on the IKB- $\alpha$ molecule, resulting in activation of NF- $\kappa \mathrm{B}$ in response to proinflammatory cytokines. ${ }^{39}$ The signalling pathways that lead to activation of $\mathrm{NF}-\kappa \mathrm{B}$ are even more complex because of the large number of different signals involved in its activation. It is possible that multiple signalling pathways become integrated to act on a novel multiprotein I $\mathrm{B}$ kinase complex. In the light of this, a large active multiprotein complex-the I $\mathrm{KB}$ kinase (IKK) - consisting of IKK-1 (identical to CHUK) and IKK-2 has been identified, which contains cytokine inducible I $\kappa \mathrm{B}$ kinase activity that phosphorylates both I $\kappa \mathrm{B}-\alpha$ and I $\mathrm{KB}-\beta$ to form the active heterodimers. ${ }^{40}$ However, intriguing questions on the composition, regulation, and function of the I $\mathrm{KB}$ kinase complex in response to diverse stimuli remain to be answered-for example, this complex may not be the unique integrator of the $N F-\kappa B$ response so that certain stimuli such as oxidants may follow other pathways to I $\mathrm{KB}$ phosphorylation and NF- $\mathrm{\kappa B}$ activation.

REGULATION OF NF- $\kappa B$ BY TNF AND IL-1

It is recognised that tumour necrosis factor $\alpha$ $(\mathrm{TNF}-\alpha)$ and IL-1 $\beta$ are pro-inflammatory cytokines involved in the pathogenesis of various inflammatory diseases. TNF- $\alpha$ and IL-1 $\beta$ induce loss of I $\kappa$ B from the cytoplasm, which is preceded by $I \kappa B$ phosphorylation and polyubiquitination of both $\mathrm{p} 105$ and $\mathrm{I} \kappa \mathrm{B}-\alpha{ }^{42}$ TNF- $\alpha$ and IL- $1 \beta$ activate NF- $\kappa$ B via distinct families of cell surface receptors and proteinprotein interactions (fig 2). ${ }^{38}$ However, both pathways utilise members of the TNF receptor associated factor (TRAF) family of adaptor proteins as signal transducers, and both pathways converge at the level of the protein kinase NIK. ${ }^{37}$ TNF dependent trimerisation of 


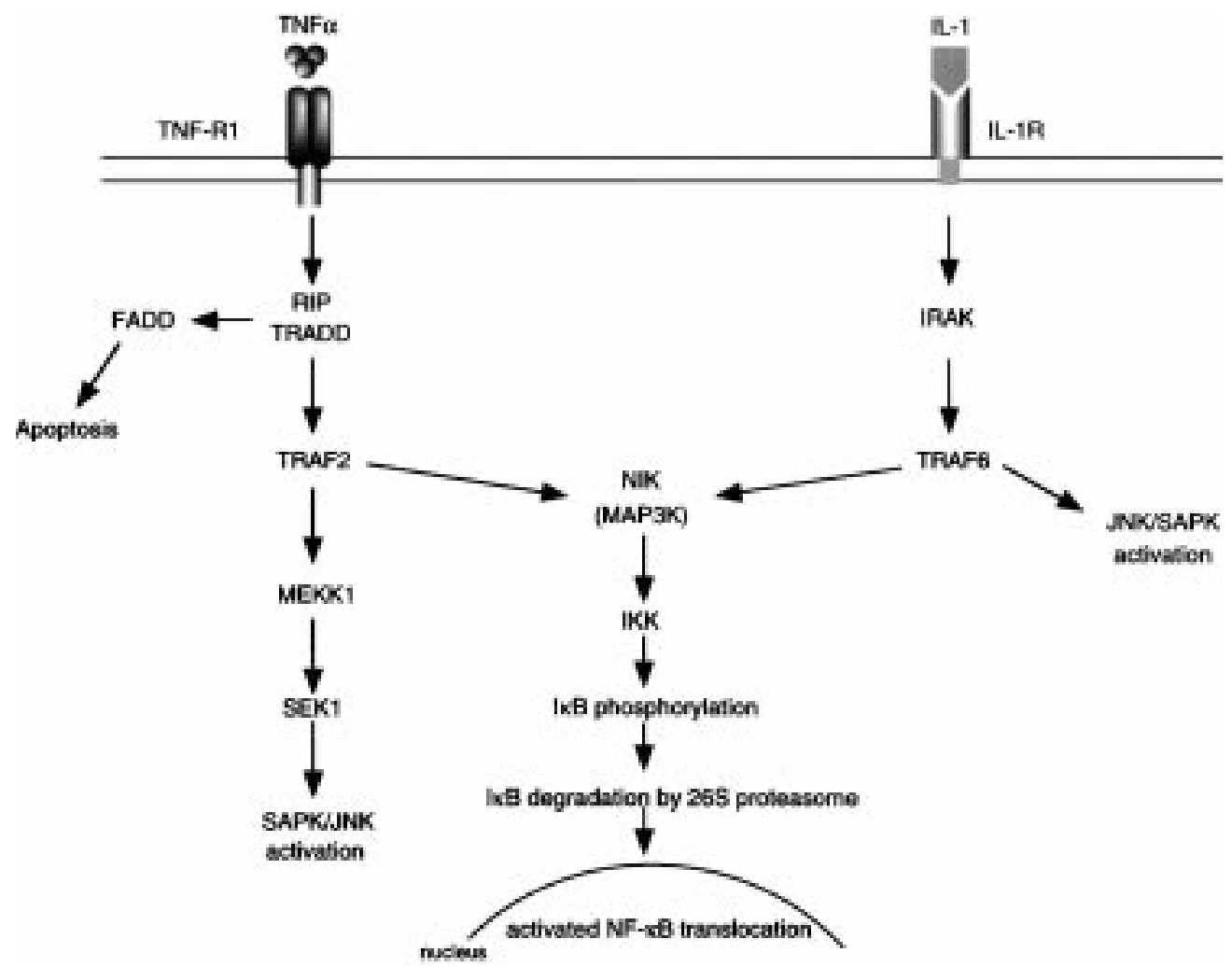

Figure 2 Model for the putative pathways for the activation of NF- $\kappa B$ initiated by TNF- $a$ and IL-1.

the TNF receptor leads to recruitment to the cell membrane of adaptor protein which is a TNF-R associated death domain protein (TRADD), receptor interacting protein (RIP) which is a death domain containing serine/ threonine kinase and, subsequently, TRAF2, and NIK. This sequence of events results in activation of NIK, which in turn activates the I $\mathrm{B}$ kinase, coupled through phosphorylation of IKK- $\alpha$ and IKK- $\beta$ in the MAPKK activation loop. This activation may occur at the cell membrane or after active NIK is released from the receptor complex. I $\mathrm{I} B-\alpha$ is then recruited to the activated $I \kappa \mathrm{B}$ kinase complex where it is phosphorylated by the IKK- $\alpha / \mathrm{IKK}-\beta$ heterodimer. The phosphorylation of I $\kappa \mathrm{B}-\alpha$ leads to its ubiquitination and degradation by the proteasome, culminating in the translocation of active $\mathrm{NF}-\kappa \mathrm{B}$ into the nucleus. In the case of the IL-1 receptor, an interaction between TRAF6 and NIK leads to the activation of the kinase complex. An alternative signal pathway that involves a mitogen activated protein kinase/ERK kinase 1 (MEKK1) or MAPKKK is also possible because MEKK1 is recruited to the TNF- $\alpha$ activated I $\mathrm{B}$ complex. ${ }^{43}$

TRANSIENT VERSUS PERSISTENT NF- $K B$ ACTIVATION

Although I $\kappa \mathrm{B}-\beta$ interacts as well with the Rel protein dimers as $\mathrm{I} \kappa \mathrm{B}-\alpha$, the two proteins display distinct responses to different NF- $\kappa B$ inducers. For example, TNF- $\alpha$ or phorbol myristate acetate (PMA) cause rapid activation of $\mathrm{NF}-\kappa \mathrm{B}$ and transient and rapid degradation

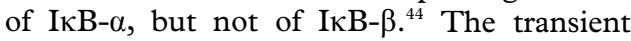
response is due to the fact that activation of $\mathrm{NF}-\kappa \mathrm{B}$ by these stimuli upregulates the expression of IкB- $\alpha$. Thus, newly synthesised

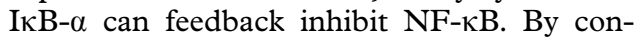
trast, induction of $N F-\kappa B$ by IL- $1 \beta$ or LPS results in degradation of both I $\mathrm{KB}-\alpha$ and $\mathrm{I} \kappa \mathrm{B}-\beta$, and the activity of $\mathrm{NF}-\kappa \mathrm{B}$ persists longer following stimulation despite the presence of

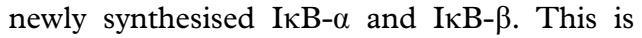
because $I \kappa \mathrm{B}-\beta$ is resynthesised as a hypophosphorylated form with an altered conformation that leaves the nuclear localising signal on NF- $\kappa \mathrm{B}$ exposed. ${ }^{45}$ The newly synthesised I $\kappa \mathrm{B}-\beta$ therefore facilitates transport of $N F-\kappa B$ as a stable complex to the nucleus for DNA binding in a manner that protects it from cytosolic I $\mathrm{KB}-\alpha$. Thus, the continued expression of NF- $\mathrm{NB}$ as a result of the hypophosphorylated form of I $\mathrm{KB}-\beta$ may lead to persistent expression of the genes induced by IL- 1 and LPS. ${ }^{44}$ The mechanism which prevents newly synthesised I $\mathrm{KB}-\alpha$ associating with activated $\mathrm{NF}-\kappa \mathrm{B}$ in the cytosol to inhibit its translocation remains to be elucidated. It may be that the rate of degradation of the two newly synthetised

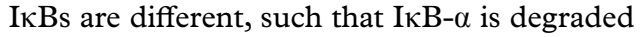
faster as a more efficient substrate for the

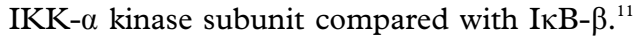
Recent studies in the Drosophila homologue of the mammalian I $\mathrm{KB}-\alpha$, a phosphoprotein cactus, show that it is rapidly phosphorylated and degraded subsequent to its biosynthesis in response to signaling. ${ }^{46} \mathrm{~A}$ further explanation may be that in immune responses, when interferon-gamma (IFN- $\gamma$ ) is present, it may not activate $\mathrm{NF}-\kappa \mathrm{B}$ itself but may synergistically enhance TNF- $\alpha$ induced persistent $\mathrm{NF}-\kappa \mathrm{B}$ activation by a mechanism that involves increased I $\mathrm{B}-\alpha$ degradation and de novo degradation of $\mathrm{I} \kappa \mathrm{B}-\beta{ }^{47}$ 
Table 3 Inflammatory genes regulated by $N F-\kappa B$

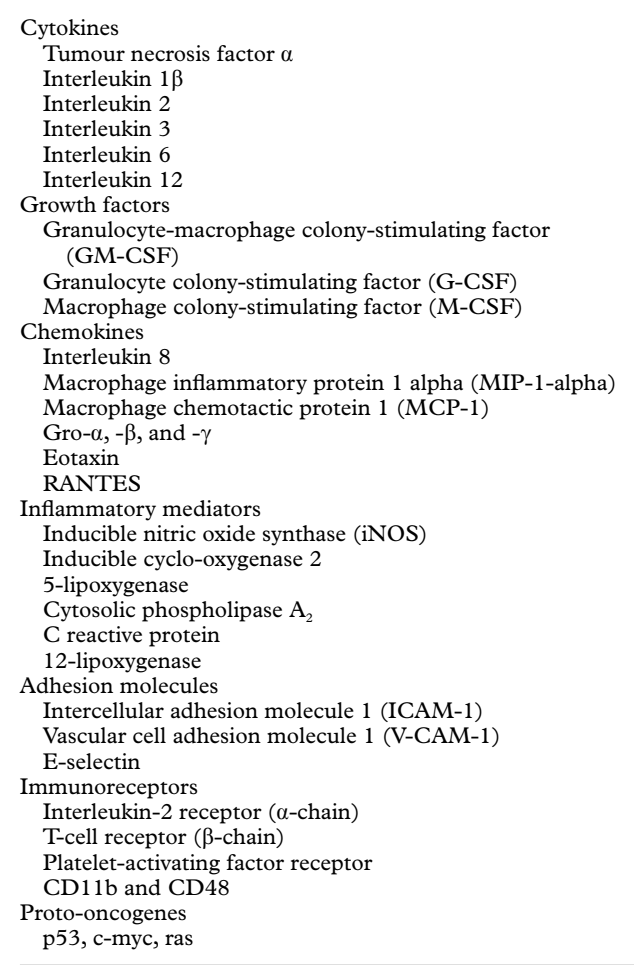

ROLE OF NF- $\kappa$ B IN PRO-INFLAMMATORY

PROCESSES

$\mathrm{NF}-\kappa \mathrm{B}$ regulates the expression of many genes involved in inflammatory responses in the lungs (table 3)..$^{1748} 49$ In all inflammatory diseases adhesion molecules have a role in recruiting inflammatory cells such as neutrophils, eosinophils, and $\mathrm{T}$ lymphocytes from the circulation to the site of inflammation. ${ }^{50}$ NF- $\kappa \mathrm{B}$ regulates the expression of several genes that encode adhesion molecules, such as intercellular adhesion molecule 1 (ICAM-1), vascular cell adhesion molecule 1 (VCAM-1), and E-selectin. Cytokine induced cell surface expression of E-selectin, VCAM-1 and ICAM-1 and the enhanced secretion of IL-8, monocyte chemoattractant protein 1 (MCP1), MHC proteins, and other chemokines are regulated at the transcriptional level in endothelial cells by the binding of $N F-\kappa B$ to its putative site in the 5 ' flanking sequences. ${ }^{16}$

In many inflammatory lung diseases such as chronic bronchitis, IPF, ARDS, and human immunodeficiency virus (HIV) depletion of intracellular GSH or increased levels of GSSG are present concomitant with the induction of inflammatory mediators and chemotactic cytokines. ${ }^{5152}$ This suggests that the intracellular redox state of the cell may have a key role in the regulation of $\mathrm{NF}-\kappa \mathrm{B}$ and the consequent potentiation of the inflammatory immune responses in lung cells. As has been mentioned earlier, $N F-\kappa B$ is involved in the regulation of genes such as E-selectin, VCAM-1, ICAM-1, IL-8, IL-6, and GM-CSF. These molecules are downregulated in endothelial cells by treatment with antioxidants. ${ }^{53}$ This is supported by studies of animal models of endotoxin induced $\mathrm{NF}-\kappa \mathrm{B}$ activation in which administration of the antioxidant NAC downregulates VCAM-1 expression and neutrophil mediated inflammation in the lungs. ${ }^{54}$ This suggests a central role for $\mathrm{NF}-\kappa \mathrm{B}$ in the activation of genes whose products promote the adhesion and extravasation of leucocytes at sites of inflammation. Hypoxia is also known to alter intracellular redox state leading to the induction of $\mathrm{NF}-\kappa \mathrm{B}$ and AP-1 DNA binding, ${ }^{55}$ which is associated with the induction of ICAM-1, iNOS, and IL-8 gene expression in endothelial cells and monocytes. $^{56-58}$ Redox regulation of NF- $\mathrm{KB}$ may therefore have a pivotal role in cells of the immune system by acting as a potent and pleiotropic transcriptional activator.

ROLE OF NF- $\mathrm{KB}$ IN APOPTOSIS

Apoptosis is an important process in the resolution of inflammation. A role of $\mathrm{NF}-\kappa \mathrm{B}$ in this process has also been suggested. TNF- $\alpha$, which is a strong inducer of $\mathrm{NF}-\kappa \mathrm{B}$, also triggers apoptosis via TNF receptor $1 .{ }^{59}$ However, the pathways leading to apoptosis and NF- $\mathrm{NB}$ activation may be distinct. By contrast, activation of NF- $\kappa \mathrm{B}$ has been shown to suppress TNF- $\alpha$ mediated apoptosis. ${ }^{60}$ These findings suggest that pro-apoptotic extracellular signals can also induce $\mathrm{NF}-\kappa \mathrm{B}$, which in turn probably induces expression of genes that are anti-apoptotic. It appears that the role of $\mathrm{NF}-\kappa \mathrm{B}$ in the regulation of apoptosis differs from cell to cell depending on their signalling pathways. ${ }^{61}$

ACTIVATION OF NF-KB IN INFLAMMATORY LUNG DISEASES

There is clear evidence for the upregulation of the genes for pro-inflammatory mediators in a number of inflammatory lung diseases. Activation of NF- $\mathrm{NB}$ has been shown in human peripheral blood mononuclear cells, airway epithelial cells (1HAE $\omega-)$ and lung tissue in response to proinflammatory cytokines such as IL- $1 \beta, T N F-\alpha$, or in response to oxidants. ${ }^{62}{ }^{63}$ However, there have been relatively few direct measurements of the activation of $N F-\kappa B$ in inflamed lungs. NF- $\kappa \mathrm{B}$ is activated in submucosal cells, in sputum derived macrophages, in endothelium, and in epithelial cells in bronchial biopsy specimens from patients with asthma ${ }^{64}$ It has been reported that in alveolar macrophages from patients with ARDS NF- $\kappa B$ is more activated than in alveolar macrophages from critically ill patients with other diseases. ${ }^{65}$ However, experimental evidence linking $\mathrm{NF}-\kappa \mathrm{B}$ activation to the human lung inflammatory diseases is lacking.

Several animal models have been developed to evaluate the role of $\mathrm{NF}-\kappa \mathrm{B}$ in lung inflammation. Intraperitoneal administration of endotoxin in rats leads to the activation of $\mathrm{NF}-\kappa \mathrm{B}$ in alveolar macrophages and in lung tissue which is associated with lung neutrophilia, epithelial permeability, and lipid peroxidation. ${ }^{54}$ In a mouse model shock caused by haemorrhage produces rapid activation of the $\mathrm{NF}-\kappa \mathrm{B}$ and the cyclic AMP response element binding protein (CREB) through xanthine oxidase dependent mechanisms in pulmonary mononuclear cells. ${ }^{66}{ }^{67}$ It has been suggested that activation of $\mathrm{NF}-\kappa \mathrm{B}$ occurs 
through $\alpha$-adrenergic stimulation by a mechanism involving the generation of reactive oxygen species (ROS). This may be the mechanism by which blood loss produces increased cytokine expression in the lungs. ${ }^{68}$

Activator protein 1 (AP-1)

C-FOS AND C-JUN PROTEINS AND THEIR INTERACTIONS

Activator protein 1 (AP-1) is an important transcription factor composed of protooncogenes as heterodimers of c-fos, c-jun or as c-jun/c-jun homodimers or activating transcription factors (ATF). AP-1 is involved in the transcriptional control of many inflammatory mediators. Activated AP-1 has been shown to disrupt the structure of the nucleosome completely. ${ }^{69}$ Nucleosome disruption is considered to be the important first step in the chromatin remodelling process involved in the initial binding of transcriptional factors to a nucleosomal template which allows the transcriptional machinery to function. Dimerisation of fos-jun or jun-jun is a prerequisite for DNA binding via a "leucine zipper" domain which serves as a crucial regulator of the expression of a wide variety of genes. ${ }^{70}$ However, such interaction is limited to the heterodimers of c-fos and c-jun only. Other members of the fos and jun family of proteins are also known to interact with each other but are unable to activate AP-1 mediated transcription. All of the Jun family of proteins are capable of forming homodimers and heterodimers which can bind to a cognate DNA site. Fos proteins do not associate with each other, but are capable of associating with any members of the Jun family to form stable dimers that have higher DNA binding activity than Jun dimers.

REGULATION OF AP-1

Activation of the tumour promoter 12-Otetradecanoylphorbol-13-acetate (TPA) response element (TRE; this element has the base sequence TGACTCA) is a prerequisite for $\mathrm{AP}-1$ induced transcriptional regulation. Hence, any agents which activate TRE, such as serum responsive factor, also activate $\mathrm{AP}-1$ by a protein kinase $C$ mediated pathway. Evidence suggests direct involvement of ROS in AP-1 activation by the c-jun $\mathrm{N}$-terminal kinases (JNKs), which are members of the MAP kinase superfamily. ${ }^{71}$ TNF- $\alpha$ induced ROS production acts as a common signal to stimulate AP-1 activation and gene expression by a novel stress activated protein kinase $(\mathrm{SAPK}) / \mathrm{JNK}{ }^{72} \mathrm{Mi}-$ togen induced AP-1 activation has been shown to be antioxidant inhibitable, suggesting that it is ROS mediated. ${ }^{73}$

However, little is known of the exact mechanism underlying ROS dependent AP-1 activation. Perturbation of cellular thiol redox status has been suggested as a signal that may be involved in the induction of c-fos and c-jun expression, since the intracellular GSH/GSSG ratio is a key regulator for the induction of stress activated signal transduction pathways by JNK and p38 kinase. $^{74}$ Depletion of intracellular GSH in airway epithelial cells following exposure to cigarette smoke free radicals leads to increased AP-1 DNA binding $^{75}$ and release of IL- $8 .{ }^{76}$ Inhibition of AP-1 activation by the antioxidant NAC, as well as prevention of the induction of c-fos and c-jun mRNA, has also been shown to occur in mesothelial cells following treatment with NAC, suggesting a direct interaction of oxidants and antioxidants with specific cysteine groups which are required for $\mathrm{AP}-1$ binding. However, contradictory data have been obtained concerning the mode of $\mathrm{AP}-1$ regulation by reduced thiols, such that NAC enhanced AP-1 DNA binding affinity and transactivation. ${ }^{35}$ Certain phenolic antioxidants such as butylated hydroxytoluene and butylated hydroxyanisole exhibit antiinflammatory effects and have been observed to increase the expression of the c-fos and c-jun mRNA substantially and to induce AP-1 DNA binding. ${ }^{77}$ Clearly the relationship between oxidants/antioxidants and transcription factor regulation is complex and requires further study.

ROLE OF AP-1 IN INFLAMMATORY PROCESSES AP-1 activation is essential for cellular proliferation and differentiation. ${ }^{70}$ However, data suggesting a role for AP-1 in inflammatory responses are few. Recent data indicating that redox sensitive JNK and p38 are activated by pro-inflammatory cytokines, such as TNF- $\alpha$ and IL-1, suggest that these signalling pathways may also have a role in inflammatory responses. Pharmacological inhibitors of p38 block many inflammatory responses, especially the production of cytokines IL- 1, TNF- $\alpha$, and IL- $6 .{ }^{78}$ The promoters of many inflammatory response genes, especially those encoding cytokines and chemokines, have AP-1 binding sites. This suggests a possible role for JNK in their regulation. JNK is also thought to be involved in the induction of cyclo-oxygenase 2 prostaglandin synthase 2 which plays an important part in the inflammatory response by catalysing the production of prostaglandins. $^{79}$ Platelet activating factor (PAF) has been implicated in the pathogenesis of allergic and inflammatory events in the airways. Binding of PAF to its receptor on human bronchial epithelial cells leads to activation of AP-1-mediated transcription. ${ }^{80}$

Direct measurements of components of $\mathrm{AP}-1$ in disease processes are lacking. AP-1 and its components c-fos and c-jun are overexpressed in lungs of smokers. ${ }^{81}$ Expression of c-jun and c-fos were induced in alveolar macrophages and type II pneumocytes in a rat model of lung fibrosis after intratracheal administration of bleomycin. ${ }^{82}$ Interestingly, c-fos is induced in epithelial cells in asthmatic subjects, suggesting a role for AP-1 in the regulation of the inflammation in asthma. ${ }^{83}$ More work will be needed to determine whether and how the JNK and p38 pathways can mediate inflammatory responses and how the components of AP-1 are involved in the pathogenesis of lung diseases. 
Nuclear factor-interleukin 6 (NF-IL6)

NF-IL6 was originally identified as a DNA binding protein responsible for IL-1 stimulated IL-6 induction. ${ }^{84}$ It has a sequence ACATTGACAATCT and direct cloning of NF-IL6 has revealed that it recognises the same nucleotide sequences as CCAAT enhancer binding protein $(\mathrm{C} / \mathrm{EBP}){ }^{7} \mathrm{NF}-\mathrm{IL} 6$ is rapidly phosphorylated and synergistically induced by LPS or inflammatory cytokines such as IL-1, TNF, and IL-6. NF-IL6 can also bind to the regulatory region of various genes including IL-8, G-CSF, IL-1, and immunoglobulin genes. ${ }^{85}$ Furthermore, NF-IL6 has been shown to be identical to IL-6DBP, a DNA binding protein responsible for IL-6 mediated induction of acute phase proteins, demonstrating that NFIL6 is involved in the expression of the genes regulated by IL- $6 .{ }^{7}$ Like NF- $\mathrm{NB}, \mathrm{NF}-\mathrm{IL} 6$ is also considered to be a pleiotropic mediator of many inducible genes involved in acute, immune, and inflammatory responses, such as the genes for IL-7, IL-8, ICAM-1, iNOS, cyclo-oxygenase- 2 genes, and several acute phase protein genes.

ROLE OF NF-IL6 IN INFLAMMATORY PROCESSES In normal lung tissue NF-IL6 mRNA and NF-IL6 protein are almost undetectable. ${ }^{86}$ However, infection of human type II pulmonary alveolar epithelial cells with respiratory syncytial virus (RSV) leads to NF-IL6 gene expression and its synthesis. ${ }^{86}$ NF-IL6 is predominantly expressed in macrophages and is activated in response to IL- $1, \mathrm{TNF}-\alpha$, and LPS. NF-IL6 regulates the E1A of adenovirus responsive promoters. ${ }^{87}$ Adenovirus E1A proteins modulate ICAM-1 induction by LPS in airway epithelial cells and may amplify the inflammatory processes in the airways of smokers and patients with COPD. ${ }^{88}$ IL- 6 levels have been shown to be higher in bronchoalveolar lavage fluid from patients with lung fibrosis and those with work related histories of long term asbestos exposure. ${ }^{89}$ In vitro studies on the effect of asbestos fibres on an airway epithelial cell line showed induction of IL-6, which is associated with the activation of both NF-IL6 and NF- $\kappa B$, which may result from an oxidant induced mechanism. ${ }^{89}$

Nuclear factor of activated $T$ cells (NFAT) The nuclear factor of activated T cells (NFAT) was first identified in the IL-2 promoter in human $\mathrm{T}$ cells. Transcription factors of the NFAT family regulate the production of effector proteins that coordinate the immune response. Despite their name, NFAT proteins are expressed not only in $\mathrm{T}$ cells, but also in other classes of immune system cells ranging from mast cells, monocytes, macrophages, and eosinophils to endothelial cells. ${ }^{6}$ NFAT proteins are activated by stimulation of receptors coupled to calcium mobilisation. Receptor stimulation and calcium mobilisation result in activation of many intracellular enzymes, including the calcium and calmodulin dependent phosphatase calcineurin, a major upstream regulator of NFAT proteins. Stimuli that elicit calcium mobilisation result in the rapid de- phosphorylation of NFAT proteins and their translocation to the nucleus where they have strong binding affinity to DNA. The amplitude and duration of calcium signals in B cells has been shown to control the differential action of $\mathrm{NF}-\kappa \mathrm{B}$ and NFAT. NF- $\kappa \mathrm{B}$ and JNK are selectively activated by a large transient rise in intracellular calcium whereas NFAT is activated by a low sustained rise in calcium. ${ }^{90}$

ROLE OF NFAT IN IMMUNE INFLAMMATORY

PROCESSES

Stimulated $\mathrm{T}$ cells transcribe a large array of activation associated genes, many of which are potential targets for NFAT; these genes encode transcription factors, signalling proteins, cytokines IL-2, IL-4, IL-5, IL-8, GM-CSF, TNF- $\alpha$, cell surface receptors, and other effector proteins. ${ }^{6}$ NFAT plays an important role in regulating the T helper 1 and 2 (Th1 and Th2) patterns of cytokine production. Th 1 cells produce IL-2 and IFN- $\gamma$ whereas Th2 cells produce IL-4, IL-5, IL-1, and IL-13. Thus, NFAT influences $T$ lymphocyte activation and the cytokine profiles of $T$ cells by differentiating Th1 and Th2 pathways, which may be important in the pathogenesis of many immune disorders. Putative GATA-3, together with NFAT sites, are present on the promoter of IL-5 which may be responsible for the induction of Th2 type cytokines. ${ }^{91}$ Since IL-5 is produced by CD $4+$ Th 2 cells, but not by Th1 cells, NFAT may play a key role in the development of eosinophilia in asthma. NFAT proteins show a characteristic ability to interact with AP-1 and NF- $\mathrm{B}$ DNA binding and transactivation. It has been shown that coupled NFAT:AP-1 is more stable and has higher affinity for DNA. ${ }^{92}$ Such interactions are important for the regulation of IL-2, IL-4, IL-5, CD40L, GM-CSF gene expression. ${ }^{6}$

As substrates for calcineurin, NFAT proteins are major targets of the immunosuppressive drugs cyclosporin A and FK506 because of their ability to inhibit dephosphorylation of NFAT. ${ }^{93}$ An understanding of the regulation and function of NFAT proteins may provide us with selective inhibitors of individual NFAT proteins in specific cell types or for selected inducible genes as a means of modulating immune responses.

Intracellular interactions of transcription factors involved in pro-inflammatory processes

The expression of most genes is controlled by the concerted action of multiple distinct transcription factors. For instance, the promoter of the IL-2 gene contains DNA binding sites for at least four distinct transcription factors: NF- $\mathrm{B}, \mathrm{AP}-1$, NFAT, and Oct factors. ${ }^{94}$ Some of these factors can physically interact with each other when bound to DNA and thereby synergistically promote DNA binding and transactivation. For example, NF- $\kappa \mathrm{B}$ has been shown to interact directly with AP-1 subunits $^{95}$ and with NFAT within the IFN- $\gamma$ promoter, ${ }^{96}$ whereas AP-1 coordinately interacts with the ets transcription factor in the collagenase promoter. ${ }^{97}$ NFAT also binds AP-1 and recruits this factor to DNA. ${ }^{6} \mathrm{NF}-\kappa \mathrm{B}$ is also 
known to synergise with a number of different transcriptional activator proteins, including Sp1, ets, c-Jun, and NF-IL6. This synergy is a consequence of the direct interactions between $\mathrm{NF}-\kappa \mathrm{B}$ and these proteins and cooperative binding to adjacent binding sites. The interactive transcription factor can be present constitutively or co-induced with NF- $\kappa \mathrm{B}$. An example of the latter is the recent finding that several inducers of NF- $\kappa \mathrm{B}$ activate the c-Jun $\mathrm{N}$-terminal protein kinase (JNK)/p38 which, in turn, phosphorylates c-Jun and synergises with NF- $\kappa \mathrm{B} .{ }^{98}$ Upregulation of E-selectin gene expression by TNF- $\alpha$ and induction of IL-8 and iNOS gene may also involve a similar mechanism..$^{99} 100$ On the other hand IL-4, which is an immunoregulatory cytokine secreted from activated Th2 lymphocytes, eosinophils, and mast cells, activates the transcription factor STAT6 ${ }^{101}$ which competes for binding to NF- $\mathrm{NB}$ binding sites. This competition leads to suppression of TNF- $\alpha$ induced E-selectin gene expression in human vascular endothelial cells. ${ }^{101}$ Thus, physical interactions between transcription factors modulate the expression of numerous inflammatory products such as adhesion molecules, cytokines, chemokines and growth factors, which are involved in the inflammatory responses in lungs.

\section{Anti-inflammatory effect of glucocorticoids on transcription factors} Glucocorticoids have been used for decades to suppress both the immune response and inflammation, yet the immunosuppressive mechanism by which these drugs act is poorly understood. There is increasing evidence that glucocorticoids inhibit the action of transcription factors such as $\mathrm{AP}-1$ and $\mathrm{NF}-\kappa \mathrm{B} .{ }^{102}$ Glucocorticoids increase the transcription of the gene encoding I $\kappa \mathrm{B}-\alpha$ and thus suppress the inflammatory process by inhibition of IL-2, IL-6, IL-8, E-selectin, and iNOS gene expression. ${ }^{103} 104$ In the cytoplasm glucocorticoids activate an intracellular receptor protein, the glucocorticoid receptor. Binding of the glucocorticoid to its receptor transduces the hormone signal to the nucleus as a transcription factor. ${ }^{102}$ Here it binds as a homodimer to glucocorticoid response elements (GRE) in steroid responsive target genes, resulting in either induction or repression of gene transcription. However, glucocorticoids decrease the transcription of the genes involved in inflammation which have no identifiable glucocorticoid response elements in their promoter regions, suggesting that some other mechanism must mediate some of the inhibitory effects of these hormones. One explanation is that there may be a direct protein-protein coupling/ interaction between the glucocorticoid receptor and $\mathrm{AP}-1^{105}$ and between the receptor and NF- $\kappa B .{ }^{106}$ Thus, the activated glucocorticoid receptors may then bind to activated $\mathrm{NF}-\kappa \mathrm{B}$, $\mathrm{AP}-1$, or CREB and prevent these transcription factors from binding to their respective consensus regions on genes. These interactions may occur in the cytoplasm or the nucleus. ${ }^{107}$ Thus, glucocorticoids are potent inhibitors of the activation of NF- $\mathrm{NB}$ and $\mathrm{AP}-1$, which may account for most of their anti-inflammatory actions. However, the relative importance of these different mechanisms to the immunosuppressive/anti-inflammatory actions of glucocorticoids remains to be established. Some in vivo support for this hypothesis comes from studies in mild asthmatic subjects in whom treatment with corticosteroids suppressed the activation of NF- $\mathrm{NB}$ and components of AP-1 in the bronchial mucosa obtained by bronchial biopsy. ${ }^{83}$

Since glucocorticoids inhibit both $\mathrm{NF}-\kappa \mathrm{B}$ and AP-1 activities, although by different mechanisms, it is not surprising that they decrease expression of a very wide range of immunoregulatory genes. It is also likely that they regulate apoptosis by direct physical interactions with p65/AP-1. However, glucocorticoids have opposite effects on apoptosis in neutrophils and eosinophils. ${ }^{108}$

\section{Nuclear receptor co-activators}

Steroid receptors and co-activator proteins are known to stimulate gene expression by facilitating the assembly of basal transcription factors into a stable pre-initiation complex. Thus, the transcription factors gain access to transcriptionally repressed chromatin to modulate the transactivation of specific gene networks. Acetylation of chromatin in vivo is coupled to transcription. Specific histone acetyltransferases (HATs) target histones bound to DNA and overcome the inhibitory effect of chromatin on gene expression. High levels of histone acetylation and linker histone deficiency are correlated with gene activity and reduced levels with gene silencing. ${ }^{109} \mathrm{~A}$ few proteins have been identified as nuclear HATs; these include steroid receptor co-activator $1,{ }^{110} \mathrm{p} 300 / \mathrm{CBP}$ associated factor (P/CAF), ${ }^{111}$ p300/CREB-binding protein (CBP), ${ }^{112}$ and TAFII230/250. ${ }^{113}$

CREB-BINDING PROTEIN (CBP ) AND P300 CBP and adenovirus E1A associated protein p300 play essential co-activator roles for a number of transcription factors including CREB, AP-1, GR, and STAT. ${ }^{8}$ CBP and p300 could interact simultaneously with more than one class of transcription factor. The amounts of these co-activator proteins are tightly controlled. Thus, for promoters that are regulated by CBP dependent transcription factors, rates of transcription will depend not only on the levels and activation state of bound transcription factors, but also on the cellular levels of $\mathrm{CBP} / \mathrm{p} 300$ and the extent to which these co-activators are utilised elsewhere. For example, the glucocorticoid receptor is the most efficient inhibitor of AP-1 activity. ${ }^{105}$

Recent studies have suggested that CBP and p300 also function as essential co-activators for several nuclear receptors including glucocorticoid receptors. ${ }^{110}$ Hence, glucocorticoid receptor antagonism of AP-1 activation may occur by competition of glucocorticoid receptors with these co-activators and therefore accounts for transrepression of genes. ${ }^{114}$ 
STEROID RECEPTOR CO-ACTIVATOR 1 (SRC-1)

SRC-1 is a co-activator for many members of the steroid hormone receptor superfamily of ligand inducible transcription factors. SRC-1 possesses intrinsic HAT activity. It also interacts with another HAT, p300/CBP associated factor $(\mathrm{P} / \mathrm{CAF})$. $^{110}$

It is likely that these co-activators and $\mathrm{P} / \mathrm{CAF}$ are recruited to the promoter regions of steroid responsive genes in vivo by interaction with steroid receptors that bind specific DNA response elements in response to ligand. The basal levels of transcription of most genes appear to be maintained by histone deacetylation which limits access to transcription factors and represses gene activation. ${ }^{115}$ However, intrinsic acetyltransferase activity of coactivators such as SRC-1, CBP and P/CAF may alter the existing equilibrium between histone acetylation and histone deacetylation towards the progressive accumulation of nucleosomes containing acetylated histones. ${ }^{115}$ This targeted histone acetylation may contribute directly to the transcriptional activation process by disrupting the repressive chromatin structure and allowing formation of the preinitiation complex in the region of the promoter nucleosome which contains the TATA box and/or initiator element. It is, however, unclear how histone acetylation and deacetylation in vivo affect steroid receptor transduction of gene expression.

\section{Implications of glucocorticoid receptor binding with nuclear co-activators in inflammatory processes}

In many chronic inflammatory disorders, such as asthma, glucocorticoid insensitivity is a rare but challenging clinical problem. The molecular basis of glucocorticoid insensitivity, however, is unknown. Abnormal numbers and availability or recruitment of nuclear receptor co-activators, their antagonism with other basal transcription factors such as AP-1, or their intrinsic acetyltransferase/deacetylase activity and chromatin remodelling, may have an important role in controlling the rate of transcription/repression of genes in various inflammatory lung diseases. In patients whose asthma is resistant to the anti-inflammatory effects of glucocorticoids, there appears to be exaggerated activation of AP-1. NF- $\kappa \mathrm{B}$ and $\beta_{2}$ agonists activate CREB that binds to and therefore sequesters activated glucocorticoid receptors inside the nucleus. ${ }^{116}$ This will reduce the availability of glucocorticoid receptors to inhibit NF- $\mathrm{NB}$ or $\mathrm{AP}-1$ or CREB which are normally active in such patients. It is also possible that these abnormal glucocorticoid receptors will not repress the transcription machinery due to alteration in HAT activity of co-activators which have impaired binding to the glucocorticoid response element. The precise role of glucocorticoids on various transcription factors and co-activators in the regulation of various cytokines, particularly in the inflammatory process, is an intense area of investigation. Understanding the mechanisms of the transcriptional machinery in normal and inflammatory disease states should provide a molecular mechanism for a novel approach to therapy.

\section{Therapeutic implications}

As described above, $\mathrm{NF}-\kappa \mathrm{B}$ and $\mathrm{AP}-1$ are activated by many of the factors which enhance the inflammatory response. This activation in turn leads to the coordinated expression of many genes that encode proteins involved in mediator synthesis and the further amplification and perpetuation of the inflammatory response. $\mathrm{NF}-\kappa \mathrm{B}$ and $\mathrm{AP}-1$ are therefore obvious targets for novel anti-inflammatory treatments. Glucocorticoids are effective inhibitors of $\mathrm{NF}-\kappa \mathrm{B}$ and AP-1 but have endocrine and metabolic side effects when given systemically. More specific $\mathrm{NF}-\kappa \mathrm{B}$ and AP-1 inhibitors could be developed which may have less serious side effects. Currently there is much interest in identifying more specific and effective NF- $\mathrm{NB}$ inhibitors. ${ }^{20}$ These include specific targets in the signalling pathway such as cytokine receptors, the DNAbinding NF- $\mathrm{NB}$ dimer itself, ubiquitin conjugating enzymes, and the proteasome. The most obvious and specific choice would be a cytokine responsive I $\mathrm{K} B$ multiprotein kinase

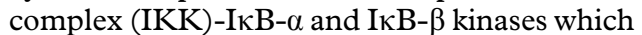
have been recently shown to activate the $I \kappa B$ in response to TNF and IL-1 ${ }^{117}$ It is probable that screening for specific IKK inhibitors, in particular, which modulate the activation and function of the IKK (IKK-1/2) is likely to have therapeutic value in the modulation of inflammatory responses. In addition, identification of the other components of the I $\mathrm{B}$ kinase complex will allow this to be targeted with novel drugs. It may also be possible to target various I $\mathrm{Bs}$ which regulate subsets of $\mathrm{NF}-\kappa \mathrm{B}$ responsive genes. A better understanding of JNK and p38 pathways in the mechanism of activation of AP-1 is required for the development of more specific anti-inflammatory drugs against the genes regulated by $\mathrm{AP}-1$.

Biochemical and clinical studies indicate that antioxidant therapy may be useful in the treatment of a wide variety of diseases by optimising the redox and antioxidant defences, or by inhibiting $\mathrm{NF}-\kappa \mathrm{B}$ activation. ${ }^{118}$ Activation and binding of transcription factors to consensus sites on DNA may be driven by the physiological redox homeostasis, especially by the intracellular thiol-disulphide balance. The endogenous glutathione and thioredoxin systems may therefore be target molecules to modulate the expression of redox sensitive cytokine, interleukin, and adhesion molecule gene expression. ${ }^{118}$

It may not, however, be logical to block the activation of NF- $\mathrm{BB}$ for prolonged periods since it plays such a critical part in the immune and other defence responses. Targeted disruption (or knockout) of the p65 component of NF- $\kappa \mathrm{B}$ is lethal in animal models because of associated developmental abnormalities ${ }^{119}$ whereas the lack of the p50 component results in immune deficiency and increased susceptibility to infection. ${ }^{13}$ Since NF- $\mathrm{\kappa B}$ often works in concert with other transcription factors, it may be possible to achieve a more selective blockade in 
specific cell types in a particular disease or a blockade of a restricted set of genes by developing compounds that inhibit the synergistic interactions between several transcription factors. For example, although there are many similarities between the inflammatory responses in patients with asthma and other inflammatory lung diseases such as COPD, there are also important differences in the type of inflammatory cells involved and in the mediators of the inflammation. These differences may relate to the secretion of specific cytokines such as IL-5, which promotes eosinophilic inflammation in patients with asthma, and TNF- $\alpha$ and IL- 8 which cause neutrophil influx in lungs of patients with COPD. Further research on the interactions between transcription factors which might mediate these differences in inflammatory lung diseases is needed. Further studies are also required to determine whether the intensity of $\mathrm{NF}-\kappa \mathrm{B}$ activation is useful as a marker for the severity of lung inflammation. It is hoped that the investigation of compounds capable of inhibiting the activation of transcription factors may lead to the development of novel treatment strategies targeted at the specific inflammatory responses in chronic inflammatory lung diseases.

Supported by the British Lung Foundation. The authors wish to thank Mr Mark Lawson and Miss Tammy Watchorn for drawing the original figures.

1 Brennan FM, Maini RN, Feldmann M. Cytokine expression in chronic inflammatory disease. Br Med Bull 1995;51:368-

2 Rahman I, MacNee W. Oxidant/antioxidant imbalance in smokers and chronic obstructive pulmonary disease. Thorax 1996;51:348-50

3 Thompson AB, Robbins RA, Romberger DJ, et al. Immunological functions of the pulmonary epithelium. Eu Respir f 1995;8:127-49.

4 Papavassiliou AG. Transcription factors. $N$ Engl $7 \mathrm{Med}$ 1995;332:45-7.

5 Barnes PJ, Karin M. Nuclear factor-кB: a pivotal transcription factor in chronic inflammatory diseases. $N$ Engl $7 \mathrm{Med}$ 1997;336:1066-71.

6 Rao A, Luo C, Hogan PG. Transcription factors of the NFAT family: regulation and function. Annu Rev Immunol 1997:15:707-47.

7 Akira S, Kishimoto T. NF-IL6 and NF- $\mathrm{KB}$ in cytokine gene regulation. Adv Immunol 1997;65:1-46.

8 Glass CK, Rose DW, Rosenfeld MG. Nuclear receptor co-activators. Current Opin Cell Biol 1997;9:222-32.

9 Sen R, Baltimore D. Multiple nuclear factors interact with the immunoglobulin enhancer sequences. Cell 1986;46: $705-16$

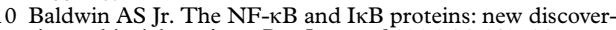
ies and insights. Annu Rev Immunol 1996;14:649-83.

11 DiDonato J, Mercurio F, Rosette C, et al. Mapping of the inducible I $\kappa \mathrm{B}$ phosphorylation sites that signal its ubiquitination and degradation. Mol Cell Biol 1996;16:1295-304

12 Chen Z, Hagler J, Palombella VJ, et al. Signal-induced sitespecific phosphorylation targets IKB- $\alpha$ to the ubiquitinproteasome pathway. Genes Dev 1995;99:1586-97.

13 Sha WC, Liou HC, Tuomanen EI, et al. Targeted disurption of the p 50 subunit of NF-kB leads to multifocal defects in immune responses. Cell 1995;80:321-30.

14 Stacey MA, Sun G, Vassalli G, et al. The allergen Der p1

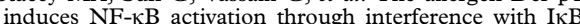
alpha function in asthmatic bronchial epithelial cells. Biochem Biophys Res Commun 1997;236:522-6.

15 Zhu Z, Tang W, Ray A, et al. Rhinovirus stimulation of interleukin- 6 in vivo and in vitro: evidence for nuclear factor $\kappa \mathrm{B}$-dependent transcriptional activation. $\mathcal{F}$ Clin Invest 1996;97:421-30

16 Baeuerle PA, Baichwal VR. NF- $\mathrm{kB}$ as a frequent target for immunosuppressive and anti-inflammatory molecules. Adv Immunol 1997;65:111-38.

17 Blackwell TS, Christman JW. The role of nuclear factor- $\mathrm{kB}$ in cytokine gene regulation. Am f Respir Cell Mol Biol 1997; 17:3-9.

18 Toledano MB , Leonard WJ. Modulation of transcription factor NF- $\mathrm{KB}$ binding activity by oxidation-reduction in vitro. Proc Natl Acad Sci 1991;88:4328-32.

19 Schulze-Osthoff K, Los M, Baeuerle PA. Redox signalling by transcription factors NF-kB and AP-1 in lymphocytes. Biochem Pharmacol 1995;50:735-41.
20 Richter, C, Cogvadze V, Laffranchi R, et al. Oxidants in Richter, C, Cogvadze V, Laffranchi R, et al. Oxidants in Acta 1995;127:67-74.

21 Shang F, Gong X, Taylor A. Activity of ubiquitin-dependent pathway in response to oxidative stress. Ubiquitinactivating enzyme is transiently up-regulated. $f$ Biol Chem 1997;272:23086-93

22 Shea LM, Beehler C, Schwartz M, et al. Hyperoxia activates $\mathrm{NF}-\kappa \mathrm{B}$ and increases TNF- $\alpha$ and IFN- $\gamma$ gene expression mouse pulmonary lymphocytes. F Immunol 1996;157: $3902-8$

23 Haddad E-B, Salmon M, Koto H, et al. Ozone induction of cytokine-induced neutrophil chemoattractant (CINC) and nuclear factor- $\mathrm{kB}$ in rat lung: inhibition by corticosteroids. FEBS Lett 1996;379:265-8.

24 Schmidt KN, Amstad P, Cerutti P, et al. The roles of hydrogen peroxide and superoxide as messengers in the activation of transfactor factor NF-kB. Chem Biol 1995;2: $13-22$.

25 Bowie, Moynagh PN, O’Neill LAJ. Lipid peroxidation is involved in the activation of NF- $\mathrm{KB}$ by tumor necrosis factor but not interleukin-1 in the human endothelial cell line ECV304. F Biol Chem 1997;272:25941-50.

26 Ginn-Pease ME, Whisler RL. Optimal NF-кB mediated transcriptional responses in Jurkat $\mathrm{T}$ cells exposed to oxidative stress are dependent on intracellular glutathione and costimulatory signals. Biochem Biophys Res Commun 1996;226:695-702.

27 Whiteside ST, Epinat JC, Rice NR, et al. I Kappa B epsilon, a novel member of the IKB family, controls RelA and cRe NF-кB activity. EMBO f 1997;16:1413-26.

28 Arenzana-Seisdedos F, Thompson J, Rodriguez MS, et al. Inducible nuclear expression of newly synthesised IкB- $\alpha$ negatively regulates DNA-binding and transcriptional

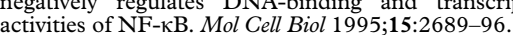

29 Klement JF, Rice NR, Car BD, et al. IאB- $\alpha$ deficiency results in a sustained NF- $\mathrm{kB}$ response and severe widespread derin a sustained NF-KB response and severe widesp
matitis in mice. Mol Cell Biol 1996;16:2341-9.

30 Baeuerle PA, Baltimore D. NF-кB: ten years after. Cell Baeuerle PA, Ba
1996;87:13-20.

31 Scheinman RI, Cogswell PC, Lofquist AK, et al. Role of transcriptional activation of IKB- $\alpha$ in mediation of immunosuppression by glucocorticoids. Science 1995;270:283-6.

32 Kazmi, SM, Plante RK, Visconti V, et al. Suppression of $\mathrm{NF}-\kappa \mathrm{B}$ activation and NF- $\kappa \mathrm{B}-d$ ependent gene expression by tepoxalin, a dual inhibitor of cyclooxygenase and 5-lipoxygenase. F Cell Biochem 1995;57:299-310.

33 Wang, P, Wu P, Siegel MI, et al. Interleukin-10 inhibits NF- $\mathrm{BB}$ activation in human monocytes. F Biol Chem 1995; 270:95558-63.

34 Pahl HL, Krauss B, Schulze-Osthoff K, et al. The immunosuppressive fungal metabolite gliotoxin specically inhibits
transcription factor NF-kB. Exp Med 1996;183:1829-40.

35 Schenk H, Klein M, Erdbrugger W, et al. Distinct effects of thioredoxin and antioxidants on the activation of transcripion factors NF-kB and AP-1. Proc Natl Acad Sci 1994;91: $1672-6$.

36 Jun DY, Chae HZ, Rhee SG, et al. Regulatory role for a novel human thioredoxin peroxidase in NF- $\mathrm{KB}$ activation. $\mathcal{F}$ Biol Chem 1997;272:30952-61.

37 Malinin NL, Boldin MP, Kovalenko AV, et al. MAP3Krelated kinase involved in NF- $\mathrm{KB}$ induction by TNF, CD95 and IL-1. Nature 1997;385:540-3.

38 Regnier $\mathrm{CH}$, Song HY, Gao X, et al. Identification and characterisation of an IкB kinase. Cell 1997;90:373-83.

39 DiDonato JA, Hayakawa $M$, Rothward DM, et al. A cytokine-responsive I $\mathrm{B}$ kinase that activates the transcription factor NF-кB. Nature 1997;388:548-54

40 Woronicz JD, Gao X, Cao Z, et al. IкB kinase- $\beta$ : NF-кB activation and complex formation with I $\mathrm{B}$ kinase- $\alpha$ and NIK. Science 1997;278:866-9.

41 Zandi E, Rothward DM, Delhase M, et al. The IкB kinase complex (IKK) contains two kinase subunits, IKK- $\alpha$ and

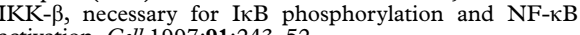
activation. Cell 1997;91:243-52.

42 Beg AA, Finco TS, Nantermet PV, et al. TNF- $\alpha$ and IL-1 ead to phosphorylation and loss of IKB- $\alpha$ : a mechansim for NF-кB activation. Mol Cell Biol 1993;13:3301-10.

43 Lee FS, Hagler J, Chen ZJ, et al. Activation of the IкB- $\alpha$ kinase complex by MEKK1, a kinase of the JNK pathway. Cell 1997;88:213-22.

44 Thompson JE, Phillips RJ, Erdjument-Bromage H, et al. I $\mathrm{B}-\beta$ regulates the persistent response in a biphasic activation of NF- $\kappa$ B. Cell 1995;80:573-82.

45 Philips RJ, Ghosh S. Regulation of IкB- $\beta$ in WEHI 231 mature B cells. Mol Cell Biol 1997;17:4390-6.

46 Packman LC, Kubota K, Parker J, et al. Casein kinase II phosphorylates Ser468 in the PEST domain of the Drosophila IкB homologue cactus. FEBS Lett 1997;400:45 50

47 Chesire JL, Baldwin AS Jr. Synergistic activation of NF-кB by tumour necrosis factor-alpha and gamma intereron via

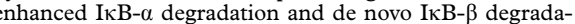
tion. Mol Cell Biol 1997;17:6746-54.

48 Xie QW, Kashiwabara Y, Nathan C. Role of transcription factor NF- $\mathrm{KB} / \mathrm{Rel}$ in induction of nitric oxide synthase. $\mathcal{f}$ Biol Chem 1994;269:4705-8.

49 Ward PA. Role of complement, chemokines and regulatory cytokines in acute lung injury. Ann NY Acad Sci 1996;796: 104-12.

50 Albelda SM, Smith CW, Ward PA. Adhesion molecules and inflammatory injury. FASEB f 1994;8:504-12.

51 MacNee W, Rahman I. Oxidants/antioxidants in idiopathic pulmonary fibrosis. Thorax 1995;50 (Suppl 1):S53-8. 
52 Droge W, Schulze-Osthoff K, Mihm S, et al. Functions of glutathione and glutathione disulfide in immunology and glutathione and glutathione disulfide in imm

53 Chen CC, Manning AM. Transcriptional regulation of endothelial cell adhesion molecules: a dominant role for NF-кB. Agents Actions 1995;47 (Suppl): 135-41.

54 Blackwell TS, Blackwell TR, Holden EP, et al. In vivo antioxidant treatment suppresses nuclear factor- $\mathrm{\kappa B}$ activation and neutrophilic lung inflammation. F Immunol 1996;157: $1630-7$.

55 Koong AC, Chen EY, Giaccia AJ. Hypoxia causes the activation of nuclear factor $\kappa \mathrm{B}$ through the phosphorylation of IкB- $\alpha$ on tyrosine residues. Cancer Res 1994;54:1425-35.

56 Zund G, Uezono S, Stahl GL, et al. Hypoxia enhances induction of endothelial ICAM-1: role for metabolic acidosis and proteasomes. Am f Physiol 1997;273:C1571-80.

57 Gess B, Shricker K, Pfeifer M, et al. Acute hypoxia upregulates NOS gene expression in rats. Am f Physiol 1997;273: R905-10.

58 Metinko AP, Kunkel SL, Standiford TJ, et al. Anoxiahyperoxia induces monocyte-derived interleukin-8. $\mathcal{F}$ Clin Invest 1992;90:791-8.

$59 \mathrm{Hsu} \mathrm{H}$, Ziong J, Goeddel DV. The TNF receptor 1 -associated protein TRADD signals cell death and NFactivation. Cell 1995;81:495-504.

$60 \mathrm{Beg}$ AA, Baltimore D. An essential role for NF- $\mathrm{\kappa B}$ in preventing TNF- $\alpha$ induced cell death. Science 1996;274 $782-4$

61 Cai Z, Korner M, Tarantino N, et al. IкB- $\alpha$ overexpression in human breast carcinoma MCF7 cells inhibits nuclear factor- $\kappa \mathrm{B}$ activation but not TNF- $\alpha$ induced apoptosis. $\mathscr{f}$ Biol Chem 1997;272:96-101.

62 Jany B, Betz R, Shreck R. Activation of the transcription factor NF- $\mathrm{KB}$ in human tracheobronchial epithelial cells by inflammatory stimuli. Eur Respir f 1995;8:387-91.

63 McDonald PP, Bald A, Cassatella MA. Activation of the NF- $\kappa \mathrm{B}$ pathway by inflammatory stimuli in human neutrophils. Blood 1997;89:3421-33.

64 Barnes PJ, Adcock IM. NF- $\kappa$ B: a pivotal role in asthma and a new target for therapy. Trends Pharmacol Sci 1997;18:4650.

65 Schwartz MD, Moore EE, Moore FA, et al. Nuclear factor- $\mathrm{\kappa B}$ is activated in alveolar macrophages from patients with acute respiratory distress syndrome. Crit Care Med 1996;24:1285-92.

66 Shenkar R, Abraham E. Hemorrhage induces rapid in vivo activation of CREB and NF- $\kappa \mathrm{B}$ in murine intraparenchymal lung mononuclear cells. Am f Respir Cell Mol Bio 1997; 16:145-52.

67 Moine P, Shenkar R, Kaneko D, et al. Systemic blood loss affects NF- $\kappa \mathrm{B}$ regulatory mechanisms in the lungs. Am Physiol 1997;273:L185-92.

68 Tulzo YL, Shenkar R, Kaneko D, et al. Hemorrhage increases cytokine expression in lung monuclear cells in mice: involvement of catecholamines in NF- $\kappa \mathrm{B}$ regulation and cytokine expression. $\mathcal{F}$ Clin Invest 1997;99:1516-24.

$69 \mathrm{Ng} \mathrm{KW}$, Ridgway P, Cohen DR, et al. The binding of a fos jun heterodimer can completely disrupt the structure of a nucleosome. EMBO f 1997;16:2072-85.

70 Karin M, Liu Z, Zandi E. AP-1 function and regulation. Curr Opin Cell Biol 1997;9:24-46.

71 Lo YYC, Wong JMS, Cruz TF. Reactive oxygen species mediate cytokine activation of c-jun $\mathrm{NH}_{2}$-terminal kinases. f Biol Chem 1996;271:15703-7.

72 Moriguchi T, Toyoshima F, Masuyama N, et al. A novel SAPK/JNK kinase, MKK 7, stimulated by TNF- $\alpha$ and cellular stresses. $E M B O \mp 1997 ; 16: 7045-53$.

73 Goldstone SD, Fragonas JC, Jeitner TM, et al. Transcription factors as targets for oxidative signalling during lymphocyte activation. Biochem Biophys Acta 1995;1263:114-22.

74 Wilhelm D, Bender $\mathrm{K}$ Knebel A, et al. The level of intracellular glutathione is a key regulator for the induction of stress-activated signal transduction pathways including Jun N-terminal protein kinases and p38 kinase by alkylating agents. Mol Cell Biol 1997;17:4792-800.

75 Rahman I, Smith CAD, Lawson MF, et al. Induction of $\gamma$-glutamylcysteine synthetase by cigarette smoke is associated with AP-1 in human alveolar epithelial cells. FEBS Lett 1996;396:21-5.

76 Mio $\mathrm{T}$, Romberger DJ, Thompson $\mathrm{AB}$, et al. Cigarette smoke induces interleukin-8 release from human bronchial epithelial cells. Am f Respir Crit Care Med 1997;155:17706.

77 Choi HS, Moore DD. Induction of c-fos and c-jun gene expression by phenolic antioxidants. Mol Endocrinol 1993; 7:1596-606.

78 Beyaert R, Cuenda A, Vanden Berghe W, et al. The p38/RK mitogen-activated protein kinase pathway regulates to tumour necrosis factor. EMBO f 1996;15:1914-23.

79 Xie W, Herschman HR. v-src induces prostaglandin synthase 2 gene expression by activation of the c-Jun
$\mathrm{N}$-terminal kinase and the c-Jun transcription factor. $\mathcal{F}$ Biol Chem 1995;270:27622-8.

80 Levan TD, Bloom JW, Adams DG, et al. Platelet-activating factor induction of activator protein-1 signalling in

81 Wodrich W, Volm M. Overexpression of oncoproteins in non-small cell lung carcinomas of smokers. Carcinogenesis 1993;14:1121-4.

82 Haase M, Koslowski R, Lengnick A, et al. Cellular distribution of c-Jun and c-Fos in rat lung before and after bleomycin induced injury. Virchows Arch 1997;431:441-8.
83 Demoly P, Chanez P, Pujol JL, et al. Fos immunoreactivity assessment on human normal and pathological bronchial biopsies. Respir Med 1995;89:329-35.

84 Isshiki H, Akira S, Tanabe O, et al. Constitutive and IL-1 inducible factors interact with the IL-1 responsive elemen in the IL-6 gene. Mol Cell Biol 1990;10:2757-64.

85 Matsusaka T, Fujiwawa K, Nishio Y, et al. Transcription factors NF-IL6 and NF-KB synergistically activate transcription of the inflammatory cytokines, interleukin 6 and interleukin 8. Proc Natl Acad Sci 1993;90:10193-7.

86 Jamaluddin M, Garofalo R, Ogra PL, et al. Inducible translational regulation of the NF-IL6 transcription factor by respiratory syncytial virus infection in pulmonary epithelial cells. F Virol 1996;70:1554-63.

87 Spergel JM, Hsu W, Akira S, et al. NF-IL6, a member of the C/EBP family, regulates E1A-responsive promoters in the absence of E1A. F Virol 1992;66:1021-30.

88 Keicho N, Elliott WM, Hogg JC, et al. Adenovirus E1A gene dysregulates ICAM-1 expression in transformed pulmonary epithelial cells. Am f Respir Cell Mol Biol 1997;16:2330 .

89 Simeonova PP, Toriumi W, Kommineni C, et al. Molecular regulation of IL- 6 activation by asbestos in lung epithelial cells: role of reactive oxygen species. F Immunol 1997;159: $3921-8$

90 Dolmetsch RE, Lewis RS, Goodnow CC, et al. Differential activation of transcription factors induced by $\mathrm{Ca}^{2+}$ response amplitude and duration. Nature 1997;386:855-8.

91 Zhang DH, Cohn L, Ray P, et al. Transcription factor GATA-3 is differentially expression in murine Th1 and Th2 cells and controls Th2-specific expression of the interleukin-5 gene. F Biol Chem 1997;272:21597-603.

92 Wofe SA, Zou P, Dotsch V, et al. Unusual Rel-like architecture in the DNA-binding domain of the transcription factor NFATc. Nature 1997;385:172-6.

93 Mattila PS, Ullman KS, Fiering S, et al. The action of cyclosporin A and FK506 suggest a novel step in the acticyclosporin A and FK506 suggest a novel step in the
vation of T lymphocytes. EMBO $f$ 1990;9:4425-33.

94 Paliogianni F, Raptis A, Ahuja SS, et al. Negative transcriptional regulation of human interleukin 2 (IL-2) gene by glucocorticoids through interference with nuclear transcription factors AP-1 and NF-AT. F Clin Invest 1993;91: 1481-9.

95 Stein B, Baldwin AS Jr, Ballard DW, et al. Cross-coupling of

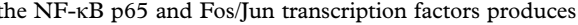
potentiated biological function. EMBO f 1993;12:3879-91.

96 Sica A, Dorman L, Viggiano V, et al. Intereraction of NF-kappaB and NFAT with the interferon-gamma promoter. F Biol Chem 1997;272:30412-20.

97 Newberry EP, Willis D, Latifi T, et al. Fibroblast growth factor receptor signaling activates the human interstitial collagenase promoter via the bipartite Ets-AP1 element. Mol Endocrinol 1997;11:1129-44.

98 Gupta S, Campbell D, Derijard B, et al. Transcription factor ATF2 regulation by the JNK signal transduction pathway. Science 1995;267:389-93.

99 Okamoto S, Mukaida N, Yasumoto K, et al. The interleukin-8 AP-1 and $\kappa \mathrm{B}$-like sites are genetic end targets of FK506-sensitive pathway accompanied by calcium mobilisation. F Biol Chem 1994;269:8582-9.

100 Read MA, Whitley MZ, Gupta S, et al. Tumor necrosis factor alpha-induced E-selectin expression is activated by the nuclear factor-kappa B and c-Jun N-terminal kinase/ p38 mitogen-activated protein kinase pathways. $\mathcal{F}$ Biol Chem 1997;272:2753-61.

101 Bennett BL, Cruz R, Lacson RG, et al. Interleukin-4 suppression of tumor necrosis factor alpha, stimulated E-selectin gene transcription is mediated by STAT6 antagonism of NF-kappa B. f Biol Chem 1997;272:10212-9.

102 Barnes PJ, Adcock I. Anti-inflammatory actions of steroids: molecular mechanisms. Trends Pharmacol Sci 993;14:436-41.

103 John M, Au BT, Jose PJ, et al. Expression and release of interleukin- 8 by human airway smooth muscle cells: inhibition by Th- 2 cytokines and corticosteroids. Am $\mathcal{F}$ Respir Cell Mol Biol 1998;18:84-90.

104 Brostjan C, Anrather J, Csizmadia V, et al. Glucocorticoids nhibit E-selectin expression by targeting NF- $\mathrm{\kappa B}$ and not ATF/c-Jun. F Immunol 1997;158:3836-44.

105 Yang-Yen HGF, Chambard JC, Sun YL, et al. Transcriptional interference between c-Jun and the glucocorticoid receptor: mutual inhibition of DNA binding due to direct protein-protein interaction. Cell 1990;62:1205-15.

106 Saag PT, Caldenhove E, Stolpe A. Molecular mechanisms of steroid action: a novel type of cross-talk between glucocorticoids and NF-KB transcription factors. Eur Respir $\mathcal{F}$

107 Adcock IM, Brown CR, Barnes PJ. Tumour necrosis factor- $\alpha$ causes retention of activated glucocorticoid receptor within the cytoplasm of A549 cells. Biochem Biophys Res Commun 1996;225:545-50.

108 Meagher LC, Cousin JM, Seckl J, et al. Opposing effects of glucocorticoids on the rate of apoptosis in neutrophilic and eosinophilic granulocytes. F Immunol 1996;156:4422-8.

109 Ura K, Kurumizaka H, Dimitrov S, et al. Histone acetylation: influence on transcription, nucleosome mobility and positioning, and linker histone-dependent

110 Spencer TE, Jenster G, Burcin MM, et al. Steroid receptor coactivator-1 is a histone acetyltransferase. Nature 1997; 389:194-8.

111 Yang XJ, Ogryzko VV, Nishikawa J, et al. A p300/CBPassociated factor that competes with the adenoviral oncoprotein E1A. Nature 1996;382:319-24. 
112 Ogryzko VV, Schiltz RL, Russanova V, et al. The transcriptional coactivators $\mathrm{p} 300$ and CBP are histone acetyltrans. Cell 1996;87:953-9.

113 Mizen CA Yan XJ Kokubo T et al. The TAFII250 subunit of TFIID has histone acetyltransferase activity. Cell 1996;87:1261-70.

114 Kamei Y, Xu L, Heinzel T, et al. A CBP integrator complex mediates transcriptional activator and $\mathrm{AP}-1$ inhibition by nuclear receptors. Cell 1996;85:1-12.

115 Jenster G, Spencer TE, Burcin MM, et al. Steroid receptor induction of gene transcription: a two-step model. Proc Natl Acad Sci 1997;94:7879-84.
116 Adcock IM, Lane SJ, Brown CR, et al. Abnormal glucocorticoid receptor-actvator protein 1 interaction in steroid-resistant asthma. $\mathcal{F}$ Exp Med 1995;182:1951-8.

117 Verma IM, Stevenson J. IкB kinase: beginning, not the end. Proc Natl Acad Sci 1997;94:11758-60.

118 Sen CK, Packer L. Antioxidant and redox regulation of gene transcription. FASEB f 1996;10:709-20.

119 Beg AA, Sha WC, Bronson RT, et al. Embroynic lethality and liver degeneration in mice lacking the Rel A component of NF-кB. Nature 1995;376:167-70. 